911.9:502.4 (47.74)

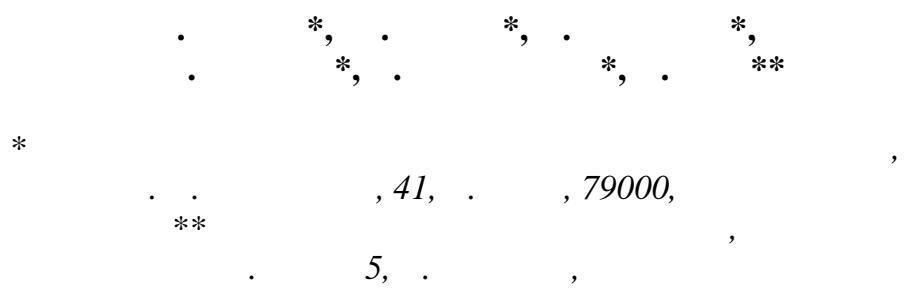

з с д х підходів європейської прогр ми екологічної мережі ( ECONET) т н ціон льної концепції формув ння екомережі кр їни розроблено територі льну модель т сх р ктеризов но ключові території укр їнсько-польського фр гмент р нск рп тської екологічної мережі. р ктеристик 23 ключових територій у меж х гірської ч стини кр їнських і ольських рп т охоплює їхню просторову лок ліз цію т опис біотичних, біотичних і природоохоронних особливостей.

лючові слов : р нск рп тськ екологічн мереж, ключові території, природоохоронні об'єкти, кр їнські рп ти, ольські рп ти.

освід європейських держ в з свідчує, що екологічні мережі ст ли інструмент ми впров дження сеєвропейської стр тегї̈ збереження біологічного $m$ л ндш фтного різном ніття ( офія, 1995) [4, 20]. озбудову екологічних мереж розгляд ють як б г то спектний процес, який передб ч є з конод вче, н уково-методичне і соці льноекономічне з безпечення. ля формув ння н’європейської екологічної мережі в жливими є дослідження в меж х тр нскордонних регіонів сусідніх європейських кр їн, н прикл д у рп т х. більшості європейських кр їн, зокрем, членів , проведено комплексні дослідження з обгрунтув ння і розробки стр тегії впров дження н ціон льних мереж ECONET, у скл ді яких виділено т кі структурні елементи: ключові території міжн родного і н ціон льного рівня т сполучні території (екокоридори) регіон льного, н ціон льного і міжн родного зн чення [6, 17-20].

н ліз регіон льних і лок льних моделей екомереж кр їньких і ольських п т свідчить про існув ння двох головних їхніх типів:

1) побудов них н з с д х н ціон льної концепцї̈ формув ння екомережк кр їни 3 кцентом н розміщення з повідних територій, $\mathrm{x}$ р ктеристиці особливостей геобот нічної і л ндш фтної структури т х р ктеру природокористув ння $[2,3,11,13,15,16]$;

2) розроблених згідно з вимог ми європейських прогр м EECONET і Natura-2000, кцентов них н вр хув нні поширення головних типів екосистем і біотопів як середовищ прожив ння фонових і рідкісних видів тв рин [4, 6, 17-20].

ціон льн екомереж ольщі побудов н згідно з прогр мою EECONET. ля вдоскон лення структури екомережі в укр їнській ч стині рп т необхідно провести повноцінні дослідження з розбудови екомережі з критеріями прогр ми EECONET.

(C) pус к ., інько ., л годир .т ін., 2010 
рп тському регіоні дрібном сшт бні схеми н ціон льних мереж ECONET розроблено в ехії, лов ччині, ольщі [17-19]. і схеми є змістовною ф ктологічною основою для обгрунтув ння т формув ння р нск рп тської екологічної мережі.

зн чимо, що ключові території польської ч стини екомережі рп т виділено н підст ві н лізу геолого-геоморфологічних т л ндш фтних чинників формув ння екомереж, оцінки поширення п нівних екосистем т рідкісних видів рослин і тв рин, т кож структури великопросторових природоохоронних об'єктів. $\mathrm{p}$ зі розбудови екологічної мережі в кр їнських рп т х в жливо вр хув ти європейський досвід з стосув ння інтегр ційних підходів у збереженні гео-, біо- т л ндш фтної різном нітності.

ьогодні розробк регіон льної схеми екологічної мережсі кр їнських рn $m$ перебув є н ст дії проектув ння. окрем , окреслено окремі ключові території екомережі н середньом сшт бному (1:1 000 000-1:200 000) рівні $[3,8,11,13,16]$. ст нніми десятиріччями в різних н укових уст нов х (інститут х, , вищих н вч льних з кл д х, з повідник х, н ціон льних природних п рк х ( ) т ін.) уз г льнено первинні д ні про місця поширення рідкісних видів рослин і тв рин у регіоні, скл дено перелік IBA територій і ділянок, що м ють особливу природоохоронну, рекре ційну т історико-культурну цінність. озроблені пропозиції щодо включення окремих ділянок регіону у н ціон льну екомережу $[2,11]$ т зроблено перші спроби проектув ння лок льних екомереж у гірській ч стині кр їнських рп т $[1,15]$.

етодологічно формув ння екомережі в кр їнських рп т х опир ється н он льній концепції розбудови екомережі $[2,3,11,16]$, у якій провідну роль у виділенні ключових територій відігр ють н явні і з проектов ні природно-з повідні об'єкти. європейських концепціях формув ння екомереж природоохоронні території є дод тковими у визн ченні місцеположення елементів екомережі, зокрем , ключових територій,

визн ч льну роль у пл нув нні просторової структури екомережі відігр ють д ні щодо розміщення непорушених господ рською діяльністю природних екосистем, рідкісних біотопів, ре лів і лок літетів р ритетних видів флори і ф уни, мігр ційних шляхів тв рин $[6,20]$.

голосимо, що суч сний рівень біокомпонентної й екосистемної вивченості кp їнських рп т не д є змоги повністю ре лізув ти європейську модель екомережі. ільшість розроблених ост ннім десятиріччям для кр їнських рп т з г лом чи окремих ii ч стин просторових моделей екомережі грунтув лись н пріоритет х н ціон льної концепції екомереж, у якій б зовими елемент ми є н явні з повідні території $[2,8,11]$.

ш мет - х р ктеристик б зових елементів р нск рп тської екологічної мережі (ключових територій) т їхньої пл нув льної моделі у меж х ольщі й кр їни. хорону ключових територій потрібно ре лізув ти шляхом визн чення зон (сфер), що поділяють територію $з$ природоохоронними вимог ми. еобхідність диференці ції зумовлен тим, що ключові території, поряд з природними ядр ми і буферними територіями, можуть охоплюв ти здегр дов ні ділянки вн слідок н дмірного лісового і сільськогоспод рського використ ння. е потребує відтворення функціон льно-просторової структури т ких територій в екомережі т поліпшення ст ну природних середовищ.

ля пл нув ння територі льного збереження біотичного і л ндш фтного різном ніття гірської ч стини кр їнських рп т обр но геогр фічно-природоохоронний в рінт н ціон льної концепцї̈ формув ння екологічних мереж, який передб ч є вр хув ння природних і господ рських чинників т н явної мережі природно-з повідного фонду (потенційні ключові території) в р зі виділення і просторової лок ліз ції елементів еко- 
мережі [2, 3]. гор х лок ліз ція ключових територій i, зокрем , їхніх природних ядер 3 н йвищими пок зник ми біологічного різном ніття здебільшого визн чен т кими чинник ми, як геолого-геоморфологічн різном нітність, особливості п леогеогр фічного розвитку, х р ктер т ет пність з селення і господ рського освоєння природних л ндш фтів. нтегрув ння природно-геогр фічної, п леогеогр фічно-історичної, г лузевогоспод рської т природоохоронної інформ ції ст ло методологічною підст вою обгрунтув ння екомережі кр їнських рп т х н регіон льному рівні $[2,3]$.

меж х кр їни в скл ді р нск рп тської екологічної мережі виділяють 12 ключових територій міжн родного і н ціон льного рівнів, які репрезентують гірські л ндш фти фізико-геогр фіної провінції хідні рп ти (див. рисунок).

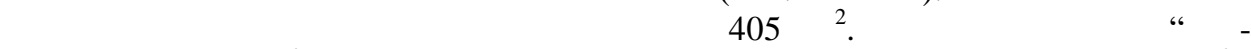
лівські ескиди” (357 км²), оляницький регіон льний л ндш фтний п рк ( $)\left(10,7 \mathrm{kM}^{2}\right)$, дв 3 к зники, три з повідні урочищ і 14 п м'яток природи. лючов територія охоплює кр йове низькогір'я і середньогір'я колівських ескидів 3 м ксим льними висот ми близько 1200 м (г. р шк (1 268,5 м), г. елен (1 227 м), г. гур (1 178 м)). оноклін льні гірські хребти утворені розірв ними і н сунутими скл дк ми (скиб ми), які скл дені флішовими пород ми, у місцях виходу ямненських пісковиків поширені комплекси скель (біля сіл рич, мельниця, убнище), в долин х річок - водосп ди. ребти утворюють шість п р лельних смуг, які проріз ють долини трию, пору і укіль. ірські хребти вкриті ялицево-буковими ліс ми, н скелях з ямненських пісковиків поширені соснові рідколісся, зн чні площі з йм ють монокультури смереки [5].

ключовій території тр пляється пон д 30 видів рідкісної для кр їни флори, т кож 20 видів ф уни, прожив є популяція зубр [10].

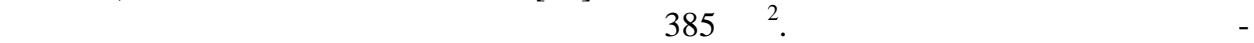
відник “ орг ни” $\left(53,4 \mathrm{kм}^{2}\right)$ т північн ч стин рп тського $\left(295 \mathrm{KM}^{2}\right)$, дв 3 к зники і дев'ять п м'яток природи. ериторія охоплює н йменш освоєні ділянки середньогір'я орг нів з вершин ми обош нк (1 754 м), иняк (1 665 м), ом'як (1 658 м). рутосхилі моноклін льні хребти скл дені флішем з перев ж нням пісковиків. хили хребтів укриті ялицево-смерековими т смерековими ліс ми, вище яких поширене криволісся з сосни гірської, гребені і вершини хребтів укриті к м'яними розсип ми (грегот ми) з лиш йниковою рослинністю. особливу ув гу з слуговують зн чні ділянки пр лісів зі смереки і сосни кедрової (релікт плейстоцену). території зрост ють 30 видів флори і тр пляються 22 види ф уни, з несені до ервоної книги кр їни ( ), один вид флори внесений до ервоної книги, , дв види - до ернської конвенції [7].

окутсько- уковинськ ключов територія площею $485 \mathrm{kM}^{2}$ охоплює територію

“ уцульщин ” i “ ижницький” (411 км²), дв 3 к зники $\left(41,8 \mathrm{kM}^{2}\right), 12$ п м'яток природи й одне $з$ повідне урочище. ериторія з йм є окутське передгір'я, острівне низькогір'я лободи унгурської, низько- і середньогірні хребти окутських і уковинських рп т, які відокремлює долин еремошу. окутське передгір'я предст влене чергув нням тер сов них долин ючки, істинки, ибниці, еремошу і міждолинних інтенсивно розчленов них височин. хні м ксим льні бсолютні висоти досяг ють 500 м і більше (г. іл $(586,7$ м), г. ичер $(568,7$ м)). ірські хребти відповід ють скл дк м, зниження між ними з йм ють поздовжні річкові долини. низькогір'ї бсолютні висоти досяг ють 800-900 м (г. ебедин (803 м), г. их лків (812 м), м ксим льні - близько 1000 м (г. пенсов (966 м) і г. гур (1 010 м), в середньогір'ї до 1500 м (г. регіт (1 472 м), г. исин осм цьк (1 466 м)). ередгір'я вкриті бучин - 
ми, низькі тер си - дібров ми, низькогірні хребти - буковими і ялицево-буковими ліс ми, у середньогір'ї домінують буково-смереково-ялицеві, ялицево-смерекові ліси, фр гмент рно тр пляються гірсько-соснове криволісся і гірські луки. олини річок збезліснені, т м розміщені сел, особливо в окутській ч стині ключової території.

“ уцульщин ” зрост є 43 види флори, з несені до ервоної книги кр їни, і по одному виду, з несеному до списку ернської конвенції і вропейського червоного списку ( ), тр пляється 39 видів хребетних і 30 видів ком х, з несених до , 12 видів ф уни - до , 24 види - до ервоного списку , 226 видів хребетних - до ернської конвенції. “ ижницький” зрост є 30 видів флори, з несених до , і один вид - до ернської конвенції, тр пляється 47 видів хребетних і 19 видів безхребетних, 3 несених до , 20 - до , 21 вид - до ервоного списку , 186 видів - до ернської конвенції [9].

жс нсько- янськ ключов територія площею $590 \mathrm{KM}^{2}$ охоплюе територію ж нського (391 км²) і дсянського (194 км²), які входять у міжн родний біосферний резерв т ( ) “ хідні рп ти”. ериторію утворюють середньо- і низькогірні хребти, відокремлені долин ми р. жз доплив ми тужиця, ошк, уснинський, ют т блуньк у верхів’і ністр . ксим льні висоти не перевищують 1300 м (г. ременець (1 221 м), г. інчик- уковський (1 251 м)). меж х ключової території проходять оловний вропейський і рп тський вододіли, беруть поч ток ріки ян і ж, між б сейн ми ж і ністр є жоцький перев л (889 м). ірські хребти вкриті буковими, подекуди яворово-буковими і ялицево-буковими ліс ми, верхню межу лісу утворює букове криволісся з домішкою вільхи зеленої і горобини, полонини з йм ють незн чні площі; долини річок з йняті сільськогоспод рськими угіддями і сел ми, особливо збезліснен територія дсянського п рку. меж х ключової території виявлено 38 видів флори і 32 види ф уни, з несені до, один вид метеликів - до , 15 видів ком х - до ернської конвенції $[12,14]$.

иневірсько- гольсько- ироколуж нськ ключов територія 3 йм є площу $560 \mathrm{kM}^{2}$. Пї̈ скл д увійдуть “ иневир” $\left(404 \mathrm{~km}^{2}\right)$ і гольсько- ироколуж нський м сив рп тського біосферного з повідник ( $)\left(155,8 \mathrm{kM}^{2}\right)$. ериторія охоплює середньогір'я м сиву $\mathrm{p}$ сн олонинського хребт i ривододільних орг нів, розчленов ні долин ми ереблі, еликої і лої гольки, уж нки. ксим льні висоти перевищують 1500 м (г. игл нський (1 563 м), г. м’янк (1 578 м)), долини річок вріз ються до 400 м. меж х території $є$ н йбільше озеро кр їнських рп т иневир (7 г ), в гольському м сиві тр пляються к рстові печери (всього 13, н йдовш “р ружб” - пон д 1 км). ериторія вкрит н півночі ялицево-буковими і ялицево-смерековими ліс ми, н півдні буковими, н д верхньою межею букового криволісся з домішкою вільхи зеленої поширені полонини. меж х під охороною перебув є н йбільш 3 площею в вропі ділянк букових пр лісів. олин ереблі 3 йнят сел ми і сільськогоспод рськими угіддями. меж х ключової території під охороною 44 види флори т 39 видів ф уни, з несених до , 11 видів ф уни - до

$$
\text { , чотири види - до ервоної книги }[1,12,13] \text {. }
$$

видовецько- орногірськ ключов територія охоплює площу $450 \mathrm{kM}^{2}$. о ії скл ду увійдуть однойменні м сиви $\left(229,5 \mathrm{~km}^{2}\right)$ і південної ч стини рп тського $\left(195 \mathrm{kм}^{2}\right)$. ериторія охоплює н йвищі у флішових рп т х кр їни гірські м сиви орногори і видівця, відокремлені долиною орної иси, у ді п зоні висот 700-2 061 м 3 м ксим льними висот ми г. оверл (2061 м) і г. ребенескул (2037 м) у орногорі т г. лизниця $(1881$ м) н видовці. ребенем орногори проходить оловний p- 


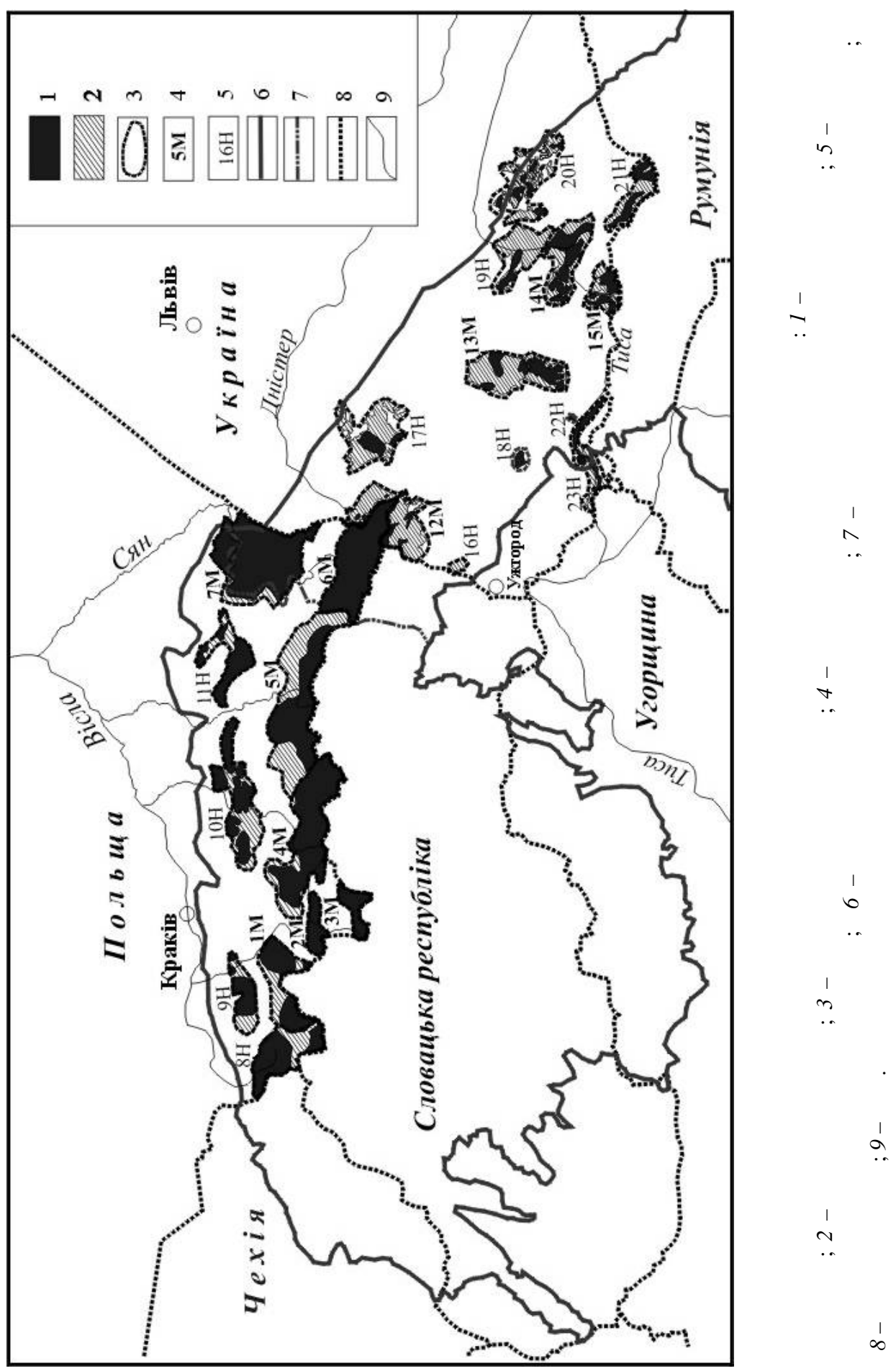


п тський вододіл, розділяючи б сейни иси, руту і еремошу. рельєфі двох гірських м сивів н йліпше в кр їнських рп т х виявився польодовиковий рельєф (к ри, к рлінги, троги, моренні утворення тощо), численними є к рові озер ( ребенескул (1 $801 \mathrm{M})$, ес мовите $(1750 \mathrm{M})$, річейк $(1510 \mathrm{M})$, ерхнє зірне $(1630 \mathrm{M})$, ижнє зірне (1 515 м), пшинець $(1487$ м), огяск, нг ряск т ін.). рослинному покриві яскр во вир жен висотн поясність, предст влені лісовий (букові, ялицевобукові, буково-ялицево-смерекові, ялицево-смерекові ліси), суб льпійський (гірськососнові т ялівцеві угрупов ння) і льпійський (луки і пустищ ) пояси. особливу ув ги з слуговують ділянки ялицево-смерекових і смерекових пр лісів, смеречники 3 домішкою сосни кедрової т високогірні луки. меж х м сиву орногори під охороною 30 видів флори, з несених у , три - до , тр пляється 32 види ф уни, 3 несені до , чотири - до ервоної книги $[1,12,13]$.

рм роську ключову територію площею $185 \mathrm{Kм}^{2}$ утворюють рм роський $\left(90 \mathrm{kм}^{2}\right)$ i узійський $\left(49 \mathrm{~km}^{2}\right)$ м сиви т один 3 к зник. ериторія охоплює високогір'я рм роського м сиву т середньогірний хребет н межиріччі иси і осівської, що скл дені крист лічними й мет морфічними пород ми. бсолютні висоти у рм роші досяг ють 1900 м (г. іп- в н рм роський $(1937$ м)), в узійському м сиві - 1400 м (г. исин (1 409 м)). високогір'ї н йяскр віше в кр їнських рп т х вир жений льпінотипний рельєф, н явні польодовикові форми рельєфу. ут добре вир жені лісовий (букові, буково-ялицеві, ялицево-смерекові і смерекові ліси), суб льпійський (гірсько-соснове криволісся) і льпійський (луки і пустищ ) пояси. узійському м сиві предст влений тільки лісовий пояс, який утворюють бучини і яворові бучини, тр пляються дубово-букові ліси т зон льні смеречники. особливу ув гу тут з слуговують дубово-букові ліси з дубом звич йним і дубом скельним, що сяг ють висоти 1090 м, і екземпляри тис ягідного, у рм роші - букові і смерекові пр ліси. меж х ключової території з фіксов но 24 і п’ять видів флори т 25 і 20 видів ф уни, з несених, відповідно до i $\quad$ три види ф уни - до ервоної книги $\quad[1,12]$.

ивчинсько- ринявськ ключов територія м є площу $215 \mathrm{kM}^{2}$ й охоплює еремоський $\left(65,5 \mathrm{KM}^{2}\right)$, три 3 к зники $\left(68,5 \mathrm{KM}^{2}\right), 13$ п м'яток природи. ешод вно тут створено ерховинський і еремоський . ериторія охоплює середньогірні хребти ивчинів і риняви у верхів'ї ілого і орного еремошів, які скл дені, відповідно, крист лічними і флішовими пород ми. бсолютні висоти у ивчин х перевищують 1600 м (г. ивчин (1 771 м), г. остун (1 653 м), г. ом н (1 763 м)), н хребт х неве і ровиця перевищують 1500 м (г. орниця $(1553$ м)). в пнякових пород $\mathrm{x}$ розвинуті к рстові печери (“ олочні бр ття” глибиною 39 м). хили гірських хребтів укриті буково-ялицевими, ялицево-смерековими і смерековими ліс ми, що переходять у гірськососнове криволісся, вище якого поширені полонини. ут зрост є пон д десять видів флори, з несених до ервоної книги кр їни [15].

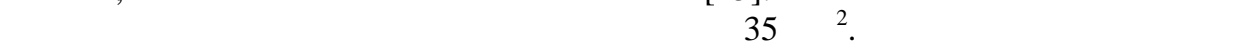
п м'ятки природи і з проектов ний л ндш фтний п рк. ериторія охоплює низькогірний б сейн ирого отоку і хребет онтош н пр вобережжі ж, що скл дені вулк ногенними пород ми, які ч сто утворюють м льовничі скелі. ірські хребти не досяг ють 1000 м (г. опричний ерх $(995$ м)). хні схили вкриті бучин ми, вздовж долини р. ж тягнуться дубово-букові ліси. сусідній лов ччині з територією межує охоронн л ндш фтн обл сть “ игорл т".

ри вськ ключов територія площею $72 \mathrm{KM}^{2}$ охоплює “ ч ров ний кр й” $\left(61 \mathrm{kM}^{2}\right)$ і одну п м'ятку природи. ериторія предст влен низькогір'ям н межиріччі 
рш ви, инячки і усинки з вершиною ужор (1 085 м). омп ктний гірський м сив скл дений вулк нічними пород ми, тр пляються вулк ногенні форми рельєфу (скелясті к льдери зг слих вулк нів, скелі ( мерековий к мінь), місцями з озер ми, л вові утворення тощо). сив укритий буковими ліс ми.

устськ ключов територія м є площу $10 \mathrm{kм}^{2}$ й охоплюе м сив “ олин н рцисів" $\left(2,5 \mathrm{kм}^{2}\right)$. е плоск н дз пл вн тер с р. устець (180-200 м) з прилеглими горбогір'ями (до 379 м). ер с вкрит зл ковими і зл ково-різнотр вними лук ми й ч г рниковими з ростями (чорновільшняки і вербняки), горбогір'я - дубовими бучин ми і с д ми. ут зрост є 18 видів флори, з несених до ервоної книги кр їни. особливу ув гу з слуговує н йбільш в ередній вропі популяція н рцис вузьколистого [1, 12, 13].

иногр дівсько- исенськ ключов територія м є площу $305 \mathrm{KM}^{2}$ Й охоплює м сив “орн гор” $\left(7,5 \mathrm{kM}^{2}\right)$ т проектов ний у долин х річок иси і орж ви. орн гор (508 м) репрезентує вулк нічне горбогір'я, вкрите буковими і дубовими ліс ми (з дубів скельного, б г топлідного, леш мп ), остепненими і скельними фітоценоз ми. олини иси і орж ви предст влені з пл в ми з русл ми, що ме ндрують, т низькими тер с ми у меж х висот 105-195 м. олини річок укриті різном нітною рослинністю: від піонерних угрупов нь н низькій з пл ві, до лучної рослинності т фр гментів вербово-тополевих лісів-г лерей, дібров (урочищ ток, опуш, еликий ic) і чорновільшняків н високій з пл ві й тер с х. ут зрост є близько десяти видів флори і пон д 20 видів ф уни, з несених до , т 43 види тв рин зі списків ернської конвенції.

лючові території польської ч стини екологічної мережі рп т виділено н підст ві н лізу геолого-геоморфологічних т л ндш фтних чинників формув ння екомереж, оцінки поширення перев жних екосистем т рідкісних видів рослин і тв рин,

т кож структури великопросторових природоохоронних об'єктів. схемі ECONET-

ольщ у скл ді р нск рп тської екомережі виділено 11 ключових територій міжн родного і н ціон льного рівнів, з яких дев'ять репрезентують фізико-геогр фічну провінцію хідні рп ти, дві- хідні рп ти [17].

лючов територія льонського ескиду охоплює площу $695 \mathrm{~km}^{2}$, у меж х якої є вісім резерв тів природи (з к зників) і з пл нов но створити п рк кр йообр зовий (л ндш фтний п рк) ескиду льонського. ериторія з йм $є$ південну н йменш нтропогенно перетворену з хідну ч стину ескидського низькогір'я. ксим льн бсолютн висот цієї території - р ня ур - досяг є 1220 м, висоти більшості хребтів не перевищують 1000 м, тут нем високогір'я. озт шув ння н кр йньому з ході

рп тської дуги і зн чн кількість оп дів (близько 1200 мм/рік) зумовили поширення великої кількості субоке нічних видів, х р ктерних для удетів, одн к нетипових для інших ч стин рп т. лизькість ор вської р ми, відповідно, сприяе проникненню рослин з півдня вропи. стіше, ніж в інших ч стин х рп т, тут тр пляються низинні торфовищ .

лючов територія ивецького ескиду з йм є площу $761 \mathrm{kM}^{2}$. її скл ді $€$

б'ягурський п рк н родовий (н ціон льний п рк) площею $17 \mathrm{kм}^{2}$, який з пл нов но розширити, ивецький л ндш фтний п рк (359 км² з охоронною зоною $\left.218 \mathrm{kм}^{2}\right)$, п'ять резерв тів, біосферний резерв т $\mathrm{T}$ з пл нов но створити б'ягурський л ндш фтний п рк. ериторія охоплює н йвище підняття зовнішніх хідних рп т 3 вершиною б'я (1 725 м). изькогірний ярус тут сяг є висот близько 1150 м н.р.м., зн чн ч стин ключової території розміщен у середньогір'ї. вершин х б'я і 
ільско поширені суб льпійськ (н висот х близько 1650 м), н б’ї - льпійськ смуг рослинності. н чн ч стин території з ліснен, зокрем, н крутих схил х $\mathrm{i}$ привершинних рівнях. олини річок перев жно збезліснені, ліси сильно видозмінені.

дн к тут збереглося 6 г то вододілів з природною рослинністю, місцями тр пляються пр ліси. н чно ліпше збереглися ліси в середньогірній смузі т рослинність високогір'я.

лючов територія лого ескиду площею $385 \mathrm{kM}^{2}$ охоплюе три резерв ти. ут 3 пл нов но створити л ндш фтний п рк лих ескидів. ериторія 3 йм є одне 3 н йнижчих п сом хідних ескидів 3 н йвищою вершиною 933 м, більш ії ч стин охоплює передгір'я. вдяки інтенсивному ерозійному розчленув нню (відносні висоти досяг ють 500 м) рельєф дуже різном нітний, що сприяє моз їчності рослинності (діброви, бучини, передгірні й гірські луки тощо).

лючов територія одг лянськ 3 йм є площу $258 \mathrm{kM}^{2}$, до неї входить дв резерв ти і з пл нов но створення р вського л ндш фтного п рку. ериторія розт шов н н 3 ході р всько- одг лянської рівнини, скл деної третинними пород ми, які перекриті пухкими флювіогляці льними конус ми винесення плейстоценових льодовиків трів. р ктерною рисою території $є$ поширення борових типів рослинності, серед яких домінує рідкісний у ольщі комплекс соснового бору болотного щитникового (Calamagrostio villosae - Pinetum), який вперше опис но у цій місцевості.

тр нськ ключов територія площею $274 \mathrm{KM}^{2}$ охоплює однойменні н ціон льний п рк і біосферний резерв т я територія приурочен до н йвищих у ольщі гір з повним комплексом форм рельєфу льпійського ярусу. еологічн будов неоднорідн - исокі три скл дені гр нітними пород ми, хідні три - в пняк ми. ут 3 фіксов но єдиний у ольщі комплекс високогірного ялицевого бору н в пнякових скелях (Polysticho - Piceetum), т кож чотири фітоценози н скельної к льцефільної рослинності і дв фітоценози різнотр в'я льпійського ярусу н гіпсових скелях.

лючов територія ондецк з йм є площу $1413 \mathrm{kM}^{2}$ й охоплює орч нський і

енінський н ціон льні п рки (90 км², які пл нують розширити), опр дський л ндш фтний п рк (544 км² з охоронною зоною $\left.239 \mathrm{KM}^{2}\right), 21$ резерв т т 3 пл нов но створення двох л ндш фтних п рків. ериторія об'єднує три гірські групи: н з ході розт шов ні орці з н йвищою вершиною $1311 \mathrm{м} ;$ н сході - відокремлений долиною прориву ун йця ондецкий ескид (п смо дзєйлівске (1 262 м) і м сив ворини (1 114 м), відділений від попереднього долиною прориву опр ду); н півдні - невеликий м сив енін (у ольщі висоти сяг ють 982 м, у лов ччині в лих енін х 1052 м). сиви орців і ондецкого ескиду скл дені твердими м гурськими пісковик ми, сильно розчленов ні й з ліснені. ут збереглися зн чні площі к рп тських пр лісів не лише в середньогірному ярусі, нерідко у низькогір'ї, особливо вздовж потоків.

еніни порівняно з тр ми м ють іншу геологічну будову. они утворені в пняковими пород ми верхньої крейди, зім'ятими у скл дки. ід ч с середньотретинної скл дч тості (в епоху утворення ескидів) еніни з зн ли повторного вирівнюв ння і н були вигляду вузької смуги скель серед флішових хребтів. еніни перетин є долин прориву ун йця з урвистими скелястими борт ми відносною висотою 300-500 м, н яких сформув л сь специфічн ксеротермічн рослинність н в пнякових скелях. ізном ніття рослинності енін н стільки 6 г те, що, незв ж ючи н м лі розміри гірського м сиву, його виділяють в окрему геобот нічну провінцію зі специфічною ксеротермічною тр в'яною рослинністю. 
лючов територія изьких ескидів площею $1475 \mathrm{kM}^{2}$ охоплює гурський н ціон льний п рк, влінський л ндш фтний п рк і вісім резерв тів. пл нов но створити л ндш фтний п рк изьких ескидів. ериторія з йм є вир зне пониження у рельєфі ескидів (м ксим льні висоти з польського боку сяг ють 999 м, зі слов цького - 1002 м). к 3 геологічною будовою, т к і з геобот нічними х р ктеристик ми ця територія є перехідною між хідними і хідними рп т ми. цій ділянці підтверджено місцезрост ння трьох видів рослин, що перебув ють під з грозою зникнення в вропі, 11 видів, які зник ють у ольщі, т щон йменше 19 регіон льно рідкісних видів флори.

ещ, дськ ключов територія 3 йм є площу $1633 \mathrm{kM}^{2}, \mathrm{H}$ якій є однойменний н ціон льний п рк $\left(271 \mathrm{kм}^{2}\right)$, л ндш фтні п рки існянсько- етлінський і олини яну $\left(817 \mathrm{kм}^{2}\right), 17$ резерв тів, що утворюють “хідні рп ти”. ериторія репрезентує в меж $\mathrm{x}$ ольщі як геологічну будову, т к і геобот нічні особливості провінції хідні рп ти. изько- і середньогірні хребти скл дені косош рув тими верств ми пісковиків і ргілітів (флішем), які сильно розчленов ні мережею річок. ериторія охоплює лісові м сиви, серед яких перев ж ють природні й н півприродні бучини т гірські луки. особливу ув гу з слуговують гірські луки й угрупов ння Caltho-Alnetum $з$ вільхою зеленою Alnus viridis, поширені у приполонинській смузі. меж х території зрост є сім видів, що перебув ють під з грозою зникнення в вропі, п’ять видів, які зник ють у ольщі, чотири види - у рп т х і 17 регіон льно рідкісних видів.

лючов територія енжковіцького ередгір'я 3 йм є площу $883 \mathrm{kM}^{2}$, у їі меж х $\epsilon$ чотири резерв ти і $з$ пл нов но створити л ндш фтні п рки ужновсько- єнжсковіцький і см рж нкі. ериторія з йм є середню ч стину з хідного ескидського передгір'я, включ ючи ч стину ужновского перегір'я, які сяг ють висоти 561 м. ут простяг ються типові для передгір'я хребти, скл дені перев жно пісковик ми, н йстійкіші з яких утворюють численні скелі. ериторія м $є$ моз їчний сільськогоспод рсько-лучно-лісовий л ндш фт зі зн чною ч сткою лісів, у яких збереглись численні умовно-природні вологі бучини.

лючов територія трижовсько- иновського ередгір'я охоплюе $425 \mathrm{kM}^{2}$, у меж х якої $є$ рножеско- трижовський л ндш фтний п рк $\left(258 \mathrm{~km}^{2} 3\right.$ охоронною зоною $344 \mathrm{Kм}^{2}$ ) і три резерв ти. ериторія 3 йм є дв гірські п см 3 м ксим льною висотою 592 м, які перетин є долин іслоку. моз їчному л ндш фті зн чн ч стк прип д є н ліси, серед яких збереглися великі ділянки типових к рп тських бучин, місцями пр лісів, т кож дв типи смерекового лісу і соснового бору. флорі є дв види, шо перебув ють під з грозою зникнення в вропі, т шість видів, які зник ють у ольщі.

лючов територія шемиського ередгір'я площею $1633 \mathrm{kм}^{2}$ охоплює л ндш фтні п рки лонних ур і шемиського ередгір'я (999 км²) і шість резерв тів. ериторія 3 йм є н йсхідніше в меж х ольщі передгір'я рп т - шемиське ередгір'я з висот ми до 450 м і лонні гори, що н леж ть до хідних ескидів, 3 н йвищою точкою 672 м. ериторія перев жно вкрит ліс ми, здебільшого, природного скл ду. скл ді флори н особливу ув гу з слуговує велик кількість східноєвропейських видів - східнок рп тських і понтійсько-п ннонських.

тже, у меж х ольщі й кр їни у скл ді р нск рп тської екологічної мережі виділяють 23 ключові території, які репрезентують гірські л ндш фти фізико-геогр фічних провінцій хідні і хідні рп ти (див. т блицю). 
риродно-геогр фічн репрезент тивність ключових територій

кр їнських і ольських рп т

\begin{tabular}{|c|c|c|c|c|c|}
\hline $\begin{array}{c}\text { лючові території } \\
\text { міжн родного ( ) i } \\
\text { н ціон льного ( ) рівня }\end{array}$ & $\begin{array}{l}\text { лощ } \\
\mathrm{KM}^{2}\end{array}$ & $\begin{array}{l}\text { исокогірні } \\
\text { природні } \\
\text { комплекси }\end{array}$ & $\begin{array}{l}\text { ередньогірні } \\
\text { природні } \\
\text { комплекси }\end{array}$ & $\begin{array}{c}\text { изькогірні } \\
\text { природні } \\
\text { комплекси }\end{array}$ & $\begin{array}{c}\text { ічково- } \\
\text { долинні } \\
\text { природні } \\
\text { комплекси }\end{array}$ \\
\hline 1 . ивєЦьКого ескиду & 761 & + & + & + & + \\
\hline 2 . одг лянськ & 258 & & & & + \\
\hline 3 . тр нськ & 274 & + & + & & + \\
\hline 4 . ондецк & 1413 & & + & + & + \\
\hline 5 . изьких ескидів & 1475 & & & + & + \\
\hline 6 . ещ дськ & 1633 & & + & + & + \\
\hline $\begin{array}{l}7 \text {. шемиського е- } \\
\text { редгір'я }\end{array}$ & 1633 & & & + & + \\
\hline 8 . льонських ескидів & 695 & & & + & + \\
\hline 9 . лоих ескидів & 385 & & & + & + \\
\hline $\begin{array}{l}10 \text {. єнжковіцького е- } \\
\text { редгір'я }\end{array}$ & 883 & & & + & + \\
\hline $\begin{array}{l}11 \text {. трижовсько- и- } \\
\text { новського ередгір'я }\end{array}$ & 425 & & & + & + \\
\hline $\begin{array}{l}\text { зом } y \text { ольських } \\
p n m x\end{array}$ & 9835 & & & & \\
\hline 12 . ж нсько- янськ & 590 & & + & + & + \\
\hline $\begin{array}{l}13 \text {. иневірсько- } \\
\text { гольсько- ироколуж Н- } \\
\text { ськ }\end{array}$ & 560 & + & + & + & + \\
\hline $\begin{array}{l}14 \text {. видовецько- } \\
\text { орногірськ }\end{array}$ & 450 & + & + & & + \\
\hline 15. рм роськ & 185 & + & + & & + \\
\hline 16 . игорл тськ & 35 & & & + & + \\
\hline 17 . ескидськ & 405 & & + & + & + \\
\hline 18 . рш всьК & 72 & & & + & + \\
\hline 19 . орг нськ & 385 & & + & & + \\
\hline $\begin{array}{l}20 \cdot \text { окутсько- } \\
\text { уковинськ }\end{array}$ & 485 & & + & + & + \\
\hline $\begin{array}{l}21 \text {. ивчинсько- } \\
\text { ринявськ }\end{array}$ & 215 & & + & & + \\
\hline 22 . устськ & 10 & & & & + \\
\hline $\begin{array}{l}23 \text {. иногр дівсько- } \\
\text { исеньк }\end{array}$ & 305 & & & & + \\
\hline $\begin{array}{l}\text { зом в кр ̈̈нських } \\
p n m x\end{array}$ & 3697 & & & & \\
\hline
\end{tabular}

озроблен просторов модель ключових територій р нск рп тської екологічної мережі в меж х кр їни і ольщі (див. рисунок) відобр ж є їхню лок ліз цію т внутрішню будову (природні ядр й буферні територіï). меж х ольських рп т ключові території виділені н підст ві методологічних підходів EECONET з кцентом н біогеогр фічній інформ ції, для кр їнських рп т - н 6 зі н ціон льної концепції формув ння екомережі з кцентом н розт шув ння природно-з повідних територій. 
кологічні мережі є ефективним інструментом впров дження сеєвропейської стр тегії збереження біологічного $m$ л ндш фтного різном ніття ( офія, 1995). роектув ння і впров дження екологічної мережі ольських і кр їнських рп т грунтув лось н теоретико-методологічних розробк х польських і вітчизняних дослідників щодо біогеогр фічних і геогр фічних особливостей формув ння екомереж у гірських територіях. икл д не вище є спробою узгодити головні елементи р нск pп тської екомережі н укр їнсько-польському відтинку.

н ліз регіон льних і лок льних моделей екомереж кр їнських і ольських п т свідчить про існув ння двох головних їхніх типів: 1) побудов них н 3 с д х $н$ ціон льної концепції формув ння екомережк кр їни з кцентом н розміщення з повідних територій, х р ктеристиці особливостей геобот нічної і л ндш фтної структури т х р ктеру природокористув ння; 2) розроблених згідно з вимог ми європейських прогр м EECONET і Natura-2000, кцентов них н вр хув нні поширення основних типів екосистем і біотопів як середовищ прожив ння фонових і рідкісних видів тв рин.

б'єктом дослідження були б зові елементи екологічної мережі - ключові території, які скл д ються з природних ядер і буферних територій. риродні ядр (біоцентри) - ділянки ключових територій, які м ють високі пок зники біотичного (зн чн кількість видів флори і ф уни, рослинних угрупов нь, природних середовищ (біотопів) тощо) і л ндш фтного різном ніття (оригін льний н бір геокомплексів і геологогеоморфологічних утворень) т високу н тур льність (мінім льн порушеність господ рською діяльністю). іоцентр ми перев жно є ділянки об'єктів різних к тегорій з н йсуворішим режимом охорони.

кр їнських рп т х виділено 12 ключових територій: ескидськ, орг нськ , окутсько- уковинськ, ж нсько- янськ, иневірсько- гольсько- ироколуж нськ , видовецько- орногірськ, рм роськ, ивчинсько- ринявськ, игорл тськ , рш вськ, устськ і иногр дівсько- исеньк з г льною площею $3697 \mathrm{kм}^{2}$. йвищ репрезент тивність вл стив окутсько- уковинській і иневірсько- гольсько- ироколуж нській ключовим територіям, що репрезентують високо-, середньо- і низькогірні т річково-долинні природні комплекси, н йнижч - устській і иногр дівськоисенській ключовим територіям (річково-долинні природні комплекси). йоригін льнішими є видовецько- орногірськ і иневірсько- гольсько- ироколуж нськ ключові території.

ольських рп т х виділено 11 ключових територій: льонського, ивєцького, изького і лого ескидів, одг лянськ, тр нськ , ондецьк , єнжковіцького, трижовсько- иновського і шемиського ередгір'я з г льною площею $9835 \mathrm{kм}^{2}$. йвищу репрезент тивність м ють ключов територія ивєцького ескиду, що репрезентує високо-, середньо- і низькогірні т річково-долинні природні комплекси. йоригін льніш тр нськ ключов територія.

озроблен просторов модель ключових територій р нск рп тської екомережі у меж х кр їни і ольщі грунтується н використ нні вимог європейської прогр ми EECONET ( ольські рп ти) т н ціон льної концепції формув ння екомережі ( $\mathrm{k-}$ p їнські рп ти). одель відобр ж є більшу площу і вищу ч стку ключових територій у гор х т їхню комп ктність у меж х ольських рп т порівняно 3 кр їнськими рп т ми. ля удоскон лення структури екомережі в укр їнській ч стині рп т необхідно провести повноцінні дослідження з розбудови екомережі з критеріями прогр ми EECONET. 
pус к, . інько, . л годир і ін.

1. іорізном ніття рп тського біосферного з повідник / ед. р д . . овч н, . . елягосонко [т ін.]. . $\therefore$ нтерекоцентр, 1997. $711 \mathrm{c}$.

2. $р у с к$. ., інько . ., ричевськ . . еогр фічні основи формув ння екологічної мережі в кр їнських рп т х // озвиток з повідної спр ви в кр їні і формув ння н'європейської екологічної мережі: тері ли міжн р. н ук.-пр кт. конф. м. хів, 11-13 листоп д 2008 р.). хів: “ дввірнянськ друк рня”, 2008. .61-68.

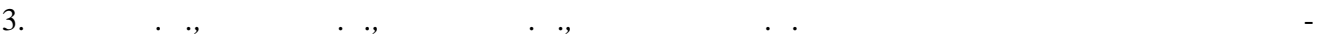
в ння екологічної мережі кр їнських рп т// із. геогр фія і геоморфологія. .: “ бріі”, 2009. . 112-123.

4. сеєвропейськ стр тегія збереження біологічного т л ндш фтного різном ніття. $\quad . \quad$ в лон, 1998. $52 \mathrm{c}$.

5. ейнек . ., ілкін . ., риндк . . іси н ціон льного природного п рку “ колівські ескиди". ьвів: ,2006. 176 с.

6. г ло . . ринципи розбудови екомережі т вибору їі територі льних елементів: укр їнськ пр ктик т європейський досвід // озвиток з повідної спр ви в кр їні і формув ння н'європейської екологічної мережі: тері ли міжн р. н ук.-пр кт. конф. м. хів, 11-13 листоп д 2008 р. хів, 2008. . 195-200.

7. лічук . ., іскевич . ., кушенко . . риродний з повідник “ орг ни”. ослинний світ. ип. 6. .: ітосоціоцентр, 2006. 400 с.

8. $р$ вчук. ., інько . ., рус $к$. . т ін. кр їнські рп ти у скл ді івденного тр нсєвропейського природоохоронного поясу // існ. ьвів. ун-ту. ер. геогр. $1997 . \quad$ ип. $20 . \quad$. 74-82. 9. оржик . ., орней . ., кільський . . т ін. ціон льний природний п рк “ ижницький” : природ , рекре ційні ресурси, менеджмент. ернівці: елен уковин , 2005. 356 с.

10. олом $x$. ., кушенко . ., $p$ м рець . . . т ін. ціон льний природний п рк “ колівські ескиди”. ослинний світ. ., 2004. 240 с.

11. опович . . сновні структурні елементи рп тської екомережі // повідн спр в в кр їні. 2007. . 13. ип. 1-2. . 80-89.

12. тойко ., дч ., имон . т ін. повідні екосистеми рп т. ьвів: віт, 1991. 248 с. 13. тойко . ., інько . ., руск.. . косистемн і л ндш фтн репрезент тивність рп тського біосферного з повідник (резерв т ) т його зн чення для формув ння екологічної мережі в рп т х // ук. $з$ п. узею природозн вств кр їни. 2004. . 20. . 123-132.

14. тойко . ., дч ., сєнкевич. . т ін. ж нський н ціон льний природний п рк. оліфункціон льне зн чення. ьвів: ерк тор, 2007. 306 с.

15. орней . ., кільський . ., оржик . . т ін. повідні об'єкти уковини з г льнодерж вного зн чення як основ регіон льної екологічної екомережі // повідн спр в в кр їні. 2001. . .. ип. 2. . 73-98.

16. еляг- осонко . ., удкін . ., оржнєв . . т ін. ціон льн екологічн мереж як скл дов ч стин н'європейської екологічної мережі. ., 2005. 62 с.

17. Liro A. Koncepcja krajowej sieci ekologicznej ECONET-Polska. Warszawa: IUCN-Poland, 1995. $205 \mathrm{~s}$.

18. Navrh narodnej ecologickej siete Slovenska-Neconet // National Ecological Network of Slovakia. Bratislawa : IUCN, 1996. $371 \mathrm{~s}$.

19. Strategia wdrazania krajowej sieci ekologicznej ECONET-Polska / Pod. red. A. Liro. Warszawa: Fundacja IUCN Poland, 1998. 272 s.

20. The Paneuropean Ecological Network. [ лектронний pecypc]: Questions and Answers. // Counsil of Europe. Strasbourg, 1998. 16 s. ежим доступу: http://www.eeconet.org/eeconet/index.html 


\title{
THE CORE AREAS OF UKRAINIAN AND POLISH CARPATHIANS WITHIN
} TRANSCARPATHIANS ECOLOGICAL NETWORK

\author{
V. Brusak*, Yu. Zinko*, S. Blagodyr*, Oks. Shevchuk*, D. Krychevska*, A. Liro** \\ * Ivan Franko National University of Lviv, \\ . Doroshenko St., 41, UA - 79000 Lviv, Ukraine \\ ** Ministry of preserve environment, Krucha St., 5, Warsaw, Poland
}

Based on approaches to the European program of econet ( ECONET) the territorial model was created and core areas of Ukrainian-Poland section of Transcarpathians ecological network were described. The characteristic of 23 core areas into mountains part of Ukrainian and Poland Carpathian include their spatial localization and also abiotic, biotic and nature preserving features.

Key words: Transcarpathians ecological network, core areas, nature protected sites, Ukrainian Carpathians, Polish Carpathians.

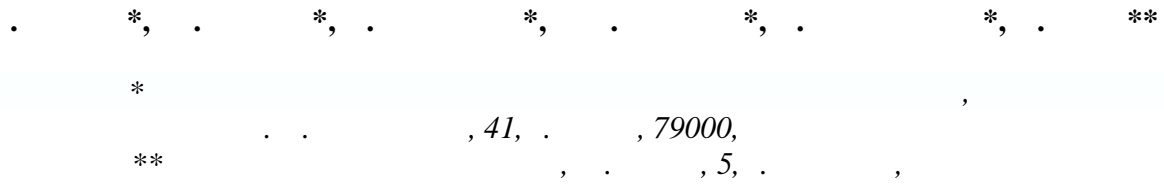

основ нии подходов европейской прогр ммы экологической сети ( ECONET) и н цион льной концепции формиров ния экосети кр ины созд но территори льную модель и ох p ктеризов но ключевые территории укр инско-польского фр гмент р нск рп тской экологической сети. $\quad$ к ктеристик 23 ключевых территорий в предел х горной ч сти кр инских и ольских рп т включ ет их простр нственную лок лиз цию, т кже биотические, биотические и природоохр нные особенности.

лючевые слов : р нск рп тск я экологическ я сеть, ключевые территории, природоохр нные объекты, кр инские рп ты, ольские рп ты.

т ття н дійшл до редколегії 22.09.2009

рийнят до друку 20.12.2009 